\title{
EPIDURAL MORPHINE AND POST-OPERATIVE PAIN RELIEF
}

\author{
A.J.C. Holland, S.K. Srikantha and J.A. Tracey
}

\begin{abstract}
Epidural morphine was compared with placebo in two randomly selected but similar groups of patients undergoing upper abdominal operations. There was no quantitative or qualitative difference in the analgesia obtained in the two groups of patients but there were significantly diminished long term requirements of intramuscular morphine in those who had been previously given epidural morphine when compared with epidural placebo. The possible causes and implications of this difference are discussed.
\end{abstract}

Key Words: Epidural Morphine, Post-Operative Analgesia, Placebo.

OPIATE RECEPTORS in the brain and spinal cord have been identified autoradiographically in animal experiments.' Potent analgesia has been produced in rats by subarachnoid injections of morphine ${ }^{2}$ and recent human studies have shown that intrathecal morphine provides good analgesia without adverse tissue reaction in the spinal cord. ${ }^{3}$ The doses used have been very small (ranging from $0.5 \mathrm{mg}$ to $1.0 \mathrm{mg}$ ) and it has been postulated that painful stimuli are blocked by an action taking place exclusively in the spinal cord. ${ }^{4-6}$.

Drugs that are injected into the epidural space may also reach the spinal cord, ${ }^{7-8}$ with the advantages of a diminished risk of infection and post-spinal headache, as well as the facility to give repeated injections by means of an epidural catheter. ${ }^{9}$ Initial reports have indicated that small doses of morphine sulphate $(2-3 \mathrm{mg}$ in $10 \mathrm{ml}$ of normal saline) have been effective in relieving acute and chronic pain, ${ }^{9}$ as well as providing analgesia both for fractured ribs ${ }^{10}$ and after lower abdominal operations. " These reports suggested, however, that epidural morphine did not completely block nervous transmission and was insufficient to provide analgesia for general sur-

A.J.C. Holland, M.B., B.S., F.F.A.R.C.S., D.C.H., Associate Professor, Department of Anaesthesia, The Montreal General Hospital, McGill University. S.K. Srikantha, M.B., B.S., F.F.A.R.C.S , Clinical Fellow, Department of Anaesthesia, The Montreal General Hospital, McGill University. J.A. Tracey, M.B., B.Ch., F.F.A.R.C.S.I., D.C.H., Clinical Fellow, Department of Anaesthesia, The Montreal General Hospital, McGill University. The Montreal General Hospital, 1650 Cedar Avenue, Montreal, P.Q. H3G IA4.

Requests for reprints and correspondence: Dr. S.K. Srikantha, Department of Anaesthesia, East Birmingham Hospital, Bordesley Green East, Birmingham B9 5ST., England. gery. It also seemed to be effective in relieving the pain of labour, possibly because the increased vascularity of the epidural space in pregnancy led to rapid clearance of the drug with a consequent inability to reach effective concentrations in the cerebrospinal fluid and spinal cord. ${ }^{12}$ In his preliminary studies, Torda found that epidural morphine provided analgesia of rapid onset (2-5 minutes) associated with a duration of 12 hours or greater. The quality of pain relief was thought to be superior to systemically administered narcotics and there was no clouding of consciousness, nausea or vomiting. ${ }^{13}$ Compared with local anaesthetic agents given by the epidural route, there seemed to be little or no risk of hypotension. If it could be shown that the administration of narcotics into the epidural space is consistently effective, it would offer considerable advantages in the provision of post-operative pain relief.

This study was designed to ascertain if there is consistent pain relief with the use of epidural morphine in doses which have been recommended and, also, to note the quality of pain relief when epidural morphine is compared with epidural placebo in major upper abdominal operations.

\section{Methods}

A total of 18 patients took part in the study; nine were given epidural morphine and nine a placebo. The patients were all in A.S.A. groups 1 and 2 and were comparable in terms of age, weight and physical condition. They were all undergoing major abdominal operations of at least two hours duration, and had received an explanation of the procedure of epidural cannulation at the time of their pre-operative assessment. 
Each patient was also told during this preoperative assessment that he or she would be receiving either morphine or saline through the epidural cannula and that the quality of pain relief was going to be assessed in the post-operative period. The patients were subsequently randomly assigned to be given epidural morphine (preservative-free morphine sulphate $3 \mathrm{mg}$ in $10 \mathrm{ml}$ of normal saline) or a placebo $(10 \mathrm{ml}$ of normal saline) by epidural catheter. Neither the anaesthetist nor the recovery room staff knew whether morphine or placebo had been injected. Anaesthesia itself followed standard practice with regards to premedication, induction and maintenance. Each patient was premedicated with morphine $10 \mathrm{mg}$ intramuscularly one hour prior to surgery, a sleep dose of thiopentone was given for induction, and pancuronium $1 \mathrm{mg}$ per $10 \mathrm{~kg}$ body weight was used for intubation and maintenance of muscle relaxation. Enflurane was used to maintain unconsciousness and the epidural catheter was inserted immediately after induction of anaesthesia. If intravenous fentanyl was used for analgesia in the course of the anaesthetic, it was not given in the last hour of the operation.

The need for analgesia was assessed clinically by the recovery room staff and the epidural injection was given when the patient became uncomfortable. (The catheter itself was removed immediately after the epidural injection had been given.) Prior to giving the epidural injection the pain was graded on a visual analogue scale ranging from 0 (no pain) to 10 (intolerable pain). Although such a method has a disadvantage of being a subjective grading. nonetheless according to most observers ${ }^{14.15}$ it seems to be a most sensitive and accurate method of comparing pain in any large number of patients.

For best assessment of response to the treatment the pain relief scale should be combined with a pain scale, and consequently 30 minutes after the epidural injection had been given the pain relief was measured by a simple descriptive rating - namely excellent, good, moderate, poor or absent.

Those patients who complained of pain at the 30 minute post-epidural assessment were given morphine $10 \mathrm{mg}$ intramuscularly. Only one epidural injection was given to each patient and all subsequent analgesia was provided by intramuscular morphine.

The patients were assessed at 30 minutes, 60 minutes, 4 hours and 12 hours after the epidural injection had been given; following the twelve hour assessment patients were sent back from the recovery room to the wards.

\section{RESULTS}

Patients were assessed 30 minutes after the epidural injection and the results are shown in Table I. There was no significant difference in the degree of pain relief between the patients in the morphine group and those in the placebo group. although both groups in general had relief of pain. It is also interesting to note that the quality of analgesia was similar in both groups.

At the 30 minute assessment four patients in the morphine group and five in the placebo group required an injection of intramuscular morphine, a difference which is of no statistical significance. In every case when intramuscular morphine was required, it was given in a dose of $10 \mathrm{mg}$.

At the end of one hour, four patients in the morphine group and eight of the nine patients in the placebo group required either a first or a repeat intramuscular injection of opiate (Table II). This was highly significant $(\mathrm{P}<0.05)$.

When the patients were assessed four hours post-operatively, the number of intramuscular injections of morphine $10 \mathrm{mg}$ that they had demanded was tabulated. The results are shown in Table III and suggest that there is a significant difference in the intramuscular analgesia requirements between those who had recieved an epidural injection of morphine and those who had received an epidural injection of placebo. Those

\section{TABLE I}

Pain SCALE Response (30 minutes after injection of Morphine or Placebo)

\begin{tabular}{cc}
\hline $\begin{array}{c}\text { Epidural Morphine Group } \\
\text { 9 Patients }\end{array}$ & $\begin{array}{c}\text { Epidural Placebo Group } \\
\text { 9 Patients }\end{array}$ \\
\hline Pain rating 8 & Pain rating 10 \\
5 & 0 \\
0 & 6 \\
10 & 4 \\
5 & 2 \\
8 & 10 \\
8 & 0 \\
1 & 10 \\
0 & 8 \\
$\frac{45}{45}$ & 50 \\
Mean $=5.1 \pm 3.7$ (S.D.) & Mean $=5.4 \pm 4.2$ (S.D.)
\end{tabular}

The rating is from 0 (no pain) to 10 (intolerable pain). Analgesia when it occurred, was qualitatively similar in the two groups. Four patients in the Morphine group demanded I. M. Morphine. Five patients in the Placebo group demanded I.M. Morphine. There was no significant difference between the groups. 
TABLE II

60 Minute Assessment

\begin{tabular}{cc}
\hline $\begin{array}{c}\text { Morphine Group } \\
\text { No. of Requirements } \\
9 \text { Patients }\end{array}$ & $\begin{array}{c}\text { Placebo Group } \\
\text { No. of Requirements } \\
\text { 9 Patients }\end{array}$ \\
\hline 0 & 1 \\
0 & 1 \\
1 & 1 \\
1 & 1 \\
1 & 0 \\
0 & 1 \\
0 & 1 \\
1 & 1 \\
4 & 1 \\
Mean $=0.44 \pm 0.53$ (S.D.) & Mean $=0.88 \pm 0.33$ (S.D.)
\end{tabular}

Significant difference in requirements between Morphine and Placebo Group: $\mathbf{P}<0.05$.

TABLE III

FOURS HOURS ASSESSMENT

\begin{tabular}{cc}
\hline \hline $\begin{array}{c}\text { Morphine Group } \\
\text { No. of I.M. } \\
\begin{array}{c}\text { Morphine Requirements } \\
\text { 9 Patients }\end{array}\end{array}$ & $\begin{array}{c}\text { Placebo Group } \\
\text { No. of I.M. } \\
\text { Morphine Requirements } \\
\text { 9 Patients }\end{array}$ \\
\hline 1 & 2 \\
1 & 1 \\
0 & 1 \\
1 & 1 \\
0 & 1 \\
1 & 2 \\
1 & 2 \\
0 & 3 \\
0 & 2 \\
5 & $\frac{15}{15}$ \\
Mcan $=0.55 \pm 0.53$ (S.D.) & Mean $=1.67 \pm 0.71$ (S.D.)
\end{tabular}

$\mathrm{P}<0.01$ : very significant.

Results: Patients in Placebo Group required an average of 1.67 doses of morphine at 4 hrs. compared with 0.55 doses for the Epidural Morphine Group. This is significant at the $\mathrm{P}<0.01$ level.

who had received placebo needed significantly more opiate to maintain analgesia than those who had been given epidural morphine.

The 12 hour assessment has been tabulated in a similar fashion and again, as Table IV shows, the patients who had received an epidural injection of morphine initially required significantly less analgesia than those who had received an epidural injection of placebo. The four tables are summarized graphically in Figure 1, which shows the difference in dose requirements of morphine between the two groups of patients in the twelve hours following operation.
TABLE IV

12 Hours AsSESSMENT

\begin{tabular}{cr}
\hline $\begin{array}{c}\text { Morphine Group } \\
\text { No. of l.M. } \\
\text { Morphine Requirements } \\
9 \text { Patients }\end{array}$ & $\begin{array}{r}\text { Placebo G } \\
\text { No. of I. } \\
\text { Morphine Req } \\
9 \text { Patie }\end{array}$ \\
\hline 2 & 2 \\
3 & 1 \\
1 & 2 \\
2 & 3 \\
0 & 1 \\
1 & 3 \\
2 & 3 \\
1 & 4 \\
1 & 3 \\
13 & 22
\end{tabular}

Mean $=1.44 \pm 0.88$ (S.D.) Mean $=2.44 \pm 1.01$ (S.D.)

$\therefore \mathrm{P}<0.05$ : statistically significant.

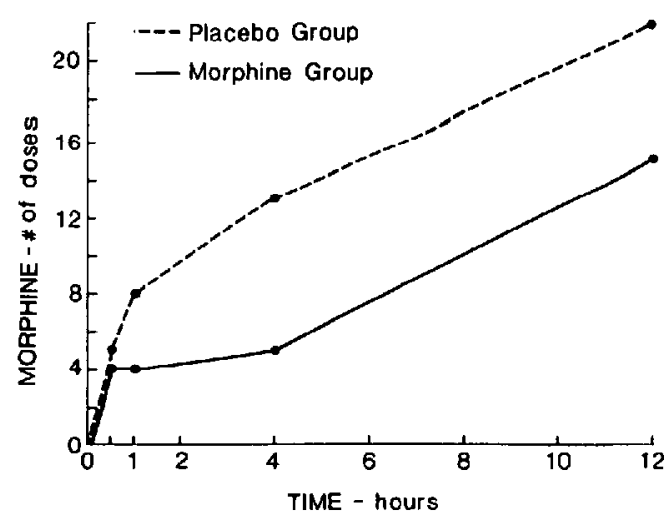

Figure 1 The number of intramuscular doses of morphine $10 \mathrm{mg}$ required by the epidural morphine group and the epidural placebo group in the twelve hours after operation.

\section{Discussion}

The use of opiates administered by the subarachnoid or epidural route has become increasingly popular over the last two or three years. Opiates are thought to act at the spinal cord level by attaching to encephalin receptors, thereby inhibiting the synaptic transmission of pain impulses. Nervous transmission is not completely blocked and so the techniques cannot be expected to provide analgesia during surgery.

In view of the articles extolling the efficacy of opiates, whether given by the subarachnoid or epidural route, the lack of pain relief that was obtained in our random group of patients when compared with those receiving placebo was disappointing. Although it is not our intention to discuss in detail the placebo effects of drugs, 
many studies have shown that post-surgical pain, for example, can be relieved by giving a drug which is not considered to have a pharmacologically active effect. ${ }^{16}$ Many studies have shown that about 30 to 35 per cent of patients will report marked relief of pain after being given a placebo. ${ }^{17}$ Although it is not clear precisely how a placebo works, and although the effect of a placebo does not diminish the reality of postsurgical pain, these studies showed that suggestion accompanied by a feeling that "something is being done," will be remarkably effective in the relief of pain. ${ }^{18}$ From the findings in this particular study the immediate pain relief observed in those patients who had received epidural morphine could have been entirely due to a placebo effect.

Epidural saline was used as the inert drug with which morphine could be compared, but a recent article by Urban has suggested that subarachnoid saline may have some analgesic effect. ${ }^{19} \mathrm{Al}$ though we used the epidural route in this study, it is a possibility worth considering that the analgesia observed in the group which had been given saline alone may have been more than just a placebo effect.

In many respects, therefore, this study closely parallels those of Husemeyer, O'Connor and Davenport, who could not relieve labour pain with epidural morphine, ${ }^{12}$ and of Selwyn Crawford who had similar results. ${ }^{20}$ We were using preservative free morphine, and Matthews has drawn attention to the fact that the preservatives contained in commonly used preparations of morphine can impair transmission in sensory nerves, which may account for some of the good results observed with intrathecal and extradural opiate injection. ${ }^{21}$

It should be pointed out that the dose of opiates administered by the epidural or subarachnoid route is by no means well established and it would certainly seem safer on clinical grounds to err on the side of giving too little, rather than giving an overdose of opiate with consequent dangers of complications, which have been described as occurring late after administration of the drug. ${ }^{4}$ Indeed, a disturbing number of recent reports have indicated that there may be delayed respiratory depression after intrathecal injection of narcotics, perhaps due to diffusion of subarachnoid opiate to the level of the cisterna magna and thence to the site of the respiratory and cardiac centers in the vicinity of the fourth ventricle. ${ }^{22-25}$

We deliberately chose the epidural route to minimize the possibility of delayed complications. Although we did not have any complications attributable to the action of opiates, it is nonetheless interesting to note that Torda and his co-workers, using extradural morphine 3 or $4 \mathrm{mg}$ in volunteers, noticed that four of the five volunteers had urinary retention and three of four males had inability to ejaculate. ${ }^{26}$ When one considers that some are using as much as $100 \mathrm{mg}$ of meperidine in the epidural space, ${ }^{27}$ the possibility of complications is very real indeed. The protagonists of epidural and intrathecal opiates have emphasized the safety of the procedure, as well as the freedom from complications. The number of clinical reports, however, that have referred to side effects such as nausea and vomiting $^{28}$ and the respiratory depression previously mentioned suggest that the technique may not be as risk-free as had at first been envisaged.

\section{Conclusion}

It has been suggested that the pain relief provided by opiates given by the epidural or subarachnoid route is due to a direct action on specific opiate receptors in the substantia gelatinosa of the posterior horn cells of the spinal cord. In support of this it has been demonstrated that opiate receptors exist in the spinal cord ${ }^{\prime}$ and that small amounts of opiate bind to these receptors to produce analgesia that can be antagonized by intrathecal naloxone in a dose-dependent fashion. ${ }^{2}$ Nonetheless the existence of endorphins and encephalins seems to be more widespread than was originally thought. Even in the central nervous system there seem to be multiple opiate receptors with distinct receptor populations of mu, delta and kappa binding sites. ${ }^{29} \mathrm{We}$ agree with those authors who suggest that there are multiple opiate receptors in the central nervous system and gastro-intestinal tract, with different characteristics, but we feel that the clinical evidence for a purely selective spinal analgesic action of opiates is not yet strong enough to warrant any dogmatism. In view of the rather disappointing results that we had with epidural morphine, the study has in some ways produced more questions than answers. As a result of this double-blind study, however, we tend to agree with Dr. Selwyn Crawford ${ }^{30}$ that analgesia is produced primarily because a certain critical but extremely small mass of drug (of the order of only 0.1 per cent of an intravenous dose) has traversed the blood brain barrier to reach sites in the brian stem, mid-brain, or cortex. ${ }^{31}$ We feel that be- 
cause of the complexity and multiplicity of opiate receptors and receptor binding it is at present too early to make the rather simplistic assertion that analgesia is produced solely by a specific spinal analgesic action.

This is not to diminish the value of the technique of epidural or subarachnoid injection of opiate, but to emphasize that there still remain many uncertainties concerning the production of analgesia when opiates are injected by these routes and that the case for a primary action at the spinal cord level is still far from proven.

\section{ACKNOWLEDGEMENTS}

We should like to acknowledge the help received by the recovery room nursing staff in carrying out many of the assessments of the patients in this study. We also acknowledge the help received from Mr. Nathan Fox and Mrs. Lyson Haccoun of the Department of Pharmacy who prepared the epidural morphine for us. We acknowledge with thanks the many hours of work put in by Ms. Dolores Kumps in typing and retyping this manuscipt.

\section{REFERENCES}

1. Pert, C.B., Kuhar, M.J. \& Snyder, S.H. Opiate receptors: Autoradiographic localization in rat brain. Proceedings of the National Academy of Sciences 73: 3729 (1976).

2. YAKSH, T.L. \& RUdY, T.A. Analgesia mediated by direct spinal action of narcotics. Science 192: 1357 (1976).

3. Wang, J.K., Nauss, L.A. \& Thomas, J.E. Pain relief by intrathecally applied morphine in man. Anesthesiology 50: 149 (1979).

4. YAKSH, T.L. Analgesic action of intrathecal opiates in cat and primates. Brain Research 155: 207 (1978).

5. YAKSH, T.L. \& Rudy, T.A. Studies on the direct spinal action of narcotics in the production of analgesia in the rat. J. Pharmac. Exp. Ther. 202: 411 (1977).

6. Yaksh, T.L., Frederickson, C.A., HuANG, S.P. \& RUDY, T.A. In vivo comparison of the receptor populations acted upon the spinal cord by morphine and pentapeptides in the production of analgeia. Brain Research 148: 516 (1978).

7. Bromage, P.R., Joyal, A.C. \& BinNey, J.C. Local anaesthetic drugs: Penetration from the spinal extradural space into the neuraxis. Science 140:392 (1963).

8. Urban, B.J. Clinical observations indicating a changing site of action during induction and recession of spinal and epidural anaesthesia. Anesthesiology 39: 496 (1973).

9. Behar, M., Olshwang, D., Magora, F. \&
Davidson, J.T. Epidural Morphine in the treatment of pain. Lancet I: 527 (1979).

10. JoHnStone, J.R. \& MCCAUghey, W. Epidural Morphine: A method of management of multiple fractured ribs. Anaesthesia 35: 155 (1980).

11. Graham, J.L., King, R. \& McCaughey, W. Post operative pain relief using epidural morphine. Anaesthesia 35: 158 (1980).

12. Husemeyer, R.P., O'Connor, M.C. \& DavenPORT, H.T. Failure of epidural morphine to relieve pain in labour. Anaesthesia 35: 161 (1980).

13. TORDA, T.A. Epidural anaesthesia with morphine - A preliminary communication. Anaesth. Intens. Care 7: 367 (1979).

14. Muskisson, C.C. Measurement of pain. Lancet 2: 1127 (1974)

15. Levill, S.L., Robinson, I.D., Rosen, M. \& Hogg, M.l.J. The reliability of a human analogue for evaluating pain. Anaesthesia 31: 1191 (1974).

16. BeECHER, H.K. Measurement of subjective responses. Oxford University Press (1959).

17. Melzack, A. The puzzle of pain. Penguin Books (1973).

18. Thorsteinsson, G., Stonnington, H.T., StillWELl, G.K. \& Elveback, L.R. The placebo effect of transcutaneous electrical stimulation. Pain 5: 31 (1978).

19. Urban, B.J. \& McKaIN, C.W Local anaesthetic effect of intrathecal normal saline. Pain 5: 43 (1978).

20. CRAwFord, J.S. Experiences with epidural morphine in obstetrics. Anaesthesia 36: 207 (1981).

21. Matthews, E. Epidural morphine. Lancet $I: 67$ (1979).

22. BoAs, R.A. Hazards of epidural morphine. Anaesth. Intens. Care 8: 377 (1980).

23. Davies, G.K., Tolhurst-Cleaver, C.L. \& JAMES, T.L. Respiratory depression after intrathecal narcotics. Anaesthesia 35: 1080 (1980).

24. Glynn, C.J., Mather, C.E., Cousins, M.J., Wilson, P.R. \& GRaham, J.R. Spinal narcotics and respiratory depression. Lancet 2: 356 (1979).

25. Liolios, A. \& ANDERSEN, F.H. Selective spinal analgesia. Lancet 2: 357 (1979).

26. Torda, T.A., Pybus, D.A., Liberman, H., Clark, M. \& Crawford, M. Experimental comparison of extradural and I.M. morphine. $\mathrm{Br}$. J. Anaesth. 52: 939 (1980).

27. Cousins, M.J., Mather, L.E., Glynn, C.J., WILSON, P.R. \& Graham, J.R. Selective spinal analgesia. Lancet $1: 1141$ (1979).

28. ScotT, D.B. \& MCClure, J. Selective epidural anaesthesia. Lancet $I: 1410$ (1979).

29. Wood, P.L., Charleson, S.E., Lane, D. \& HugGiN, R.L. Multiple opiate receptors: Differential binding of mu, kappa and delta agonists. Europ. Jour. Pharmacol. (in press).

30. Crawford, J.S. Site of action of intrathecal morphine. Br. Medical Jr. 281:680 (1980).

31. Mule, S.J. Physiological dispositions of narcotic agonists and antagonists. Narcotic Drugs: Biochemical Pharmacology. Edited by D.H. Clouet. New York, Plenum Press (1971).

32. STANLEY, T.H. Pharmacokinetics of narcotic compounds. Trends in intravenous andesthesia. Edited by J.A. Aldrete, T.H. Stanley. Chicago, Year Book Medical Publishers (1980). 


\section{RÉSUMÉ}

Le soulagement de la douleur produit par l'administration de morphine ou par celle d'un placebo par voie péridurale a été comparé chez deux groupes de patients soumis à unc chirurgie abdominale dans le cadre d'une étude à double insu. On n'a pas observé de différence significative du degré d'analgésie obtenue entre les deux groupes de patients, mais les besoins à long terme de morphine intra-musculaires ont été significativement moindres chez les sujets ayant reçu la morphine par voie péridurale que chez ceux ayant reçu le placebo. Les causes possibles et les implications de ces résultats sont discutées. 